
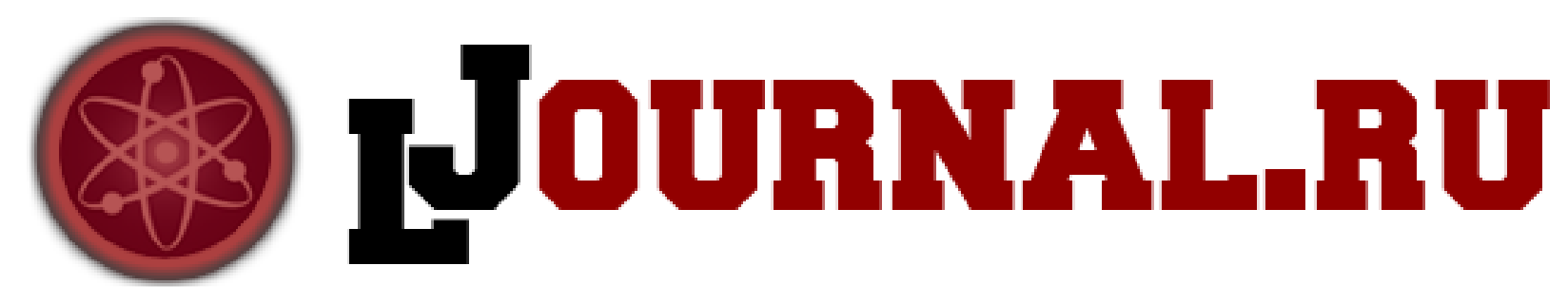

Марченков А. В.

Московский колледж архитектуры и градостроительства Москва, Россия

doi: $10.18411 / 1 \mathrm{j} 2016-2-12$

\title{
История развития профессионального образования в России (1917-конец 1950-х гг.)
}

В статье рассматриваются основные этапы развития профессионального образования в нашей стране. История развития системы профессионального образования в России-один из важнейших аспектов изучения истории страны. Отрасль профессионального образования остается на сегодняшний день одной из самых востребованных как на рынке образовательных услуг, так и на рынке вакансий.

Ключевые слова: история, этапы развития профессионального образования в советской России, школы фабрично-заводского ученичества, учебный план, методические споры.

Профессиональная школа прошла в своем историческом развитии множество этапов, и может рассматриваться как целостный социальноэкономический и исторический процесс в соответствии с определенными закономерностями развития страны. Ее становление и развитие включает в себя три направления-три исторических периода: «школа навыков», «школа профессиональных знаний, умений, навыков» и «школа профессионального 
развития личности». Впервые такая градация была представлена в монографии Малова С.Л. «История профессионального образования в России», выпущенной к юбилею трудовых резервов в 2003 году.

Основная динамика развития и формирования широкого понимания профессионального образования прослеживается в выделении следующих этапов:

Первый этап (первая половина XVI—первая половина XIX века) охарактеризован возникновением различных прообразов форм профессионального образования на первых этапах становления российской цивилизации, зарождение прообразов профессиональной школы и начало теоретического осмысления профессионального образования в доиндустриальную эпоху.

Второй этап (2-я половина XIX века-1917 год) характеризуется развитием системы профессионального образования и одновременным развитием педагогической мысли в области профессионального образования в эпоху индустриального становления России во второй половине XIX века после указов императора Александра II, который в 1875 году повелел учредить в России систему реальных училищ. Именно реальные училища явились прообразом профессионально-технических училищ и техникумов советского времени. На этом этапе происходит формирование системы государственных профессиональных учебных заведений и развитие общепедагогического движения в этой области, продлившееся до 1917 года.

После Революции 1917 года наступает третий этап (1917-1940 гг.) в развитии профессионального образования, продолжавшийся до 1940 г., включавший в себя преобразование и развитие системы среднего профессионального образования в годы становления советской экономики и первых лет индустриализации. Этот этап отличался от предшествующих и 
новой государственной идеологией (государственность, всеобщая трудовая подготовка, доступность, преемственность, бесплатность, светскость, коммунистическая идейность и др.) в области профессионального образования.

Развитие профессионального образования в этот период можно охарактеризовать как динамичный, и, одновременно, противоречивый процесс, в котором проявляется как отрицание предшествующего опыта и достижений, так и возвращение к ним. Об этих процессах в своих воспоминаниях указывают как теоретики (В. И. Байденко, Казакевич В. М., Карелин В. А. И др.), так и практики системы (Гернов Г. С., Ариончик Л. И. и др.).

После революции в Москве появилось новое поколение педагоговреформаторов, многие из которых не имели дореволюционного опыта не только управления, но и работы в образовательной системе.

3 декабря 1917 года был принят декрет СНК РСФСР «О роспуске Государственного Комитета по народному образованию», которым был создан Государственный ученый совет, занимавшийся разработкой нового содержания школьного образования, организацией форм и методов учебновоспитательной работы. Документы Государственного архива Российской Федерации говорят о том, что М.Н. Покровский, являвшийся председателем Государственного ученого совета с 1919 по I половину 1930 в черновых материалах указывает, что в 1917 - конце 1930 гг. происходит ликвидация или трансформация ранее созданных курсов, школ, училищ, открытие новых типов учебных заведений профессионального образования (школы ФЗУ, техникумы).

Возглавила эту работу Н. К. Крупская. Однако, не имея должного опыта в организации и проведении подобных мероприятий, она пыталась найти новые пути развития школьного образования, а не использовать опыт своих дореволюционных предшественников, что, конечно, явилось очень большой ошибкой. 
Ведущими идеями этого этапа, распространившимися на область начального профессионального образования, выступают политехнизм, единство школы, равноправие мужчин и женщин, взаимосвязь общего и специального образования, созидающий творческий характер учебного процесса.

К началу 1923 года на уровне Наркомпроса была разработана схема построения комплексных программ преподавания. Эта система, по замыслу разработчиков, должна была полностью заменить существовавшую ранее предметную. Аналогом этой системы явилась немецкая система изучения религии, с той лишь разницей, что всю религиозную составляющую заменили основы марксизма.

По новым образовательным программам, каждую тему каждой учебной дисциплины предлагалось рассмотреть в трех разных аспектах: природа, труд, общество. Эта схема имела совершенно логичную последовательность: к физической природе при возникновении человеческого общества был приложен труд, благодаря которому появилось сельское хозяйство и промышленность, произошел научный скачок. На этой базе должны были возникнуть определенные отношения, которые, в итоге, должны были сформировать общество, идеологию, культуру, литературу и проч. Исходя из этого, были составлены таблицы, темы в которых были расписаны по трем соответствующим колонкам. Основной ее особенностью явилось то, что вся эта система не была опробована постепенно, а вводилась директивно по всей стране. Впервые проект этой системы был предложен на педагогическом съезде 10-15 мая 1923 года в Ленинграде. Стенограммы этого съезда, изданные в 1924 году, сохранили следы весьма жарких дискуссий при обсуждении этой систем. Педагогическое сообщество разделилось на два лагеря. В воспоминаниях Б. Е. Райкова, видного ученого в области естественных наук, составляющих отдельный архивный фонд, видно это разделение. Один лагерь, под руководством Б. Е. Райкова, всячески критиковал такой подход к 
разработке программного метода образовательной системы. Его противники, под руководством преподавателя-новатора К. И. Лакиды (1886-1928), напротив, настаивали на подобном «комплексном» обучении, и, впоследствии, лоббировали их внедрение. По вопросу о внедрении комплексных программ, съезд вынес следующую резолюцию: «Ознакомившись с представленной схемой, «.....», съезд находит, что эта схема не обеспечивает соблюдения интересов естествознания в школе и, не может быть проработана его основным методом-исследовательским «.....» Однако, съезд с удовлетворением отмечает разъяснение одного из авторов программы, что программа эта является предварительной, подлежит обсуждению, и не является для школы обязательной».

Трансформация педагогических подходов на этом этапе выражается так же и в отмене существовавших дореволюционных программ, планов, методик подготовки, и предоставлении свободы в их разработке непосредственным участникам образовательного процесса. Часть прогрессивных педагогических идей, таких как педология, инженерная психология, психотехника находит свое использование во вновь разрабатываемых методиках начального профессионального образования. Создаются новые научные центры Центральный институт труда $(1921-1940$ гг.), отраслевые научноисследовательские институты, изучающие различные аспекты начальной профессиональной подготовки. Теоретические дискуссии, столкновение различных точек зрения, плюрализм и свобода педагогического творчества, делают данный этап временем инновационных методических находок (система свободного коллективного продвижения бригад, лабораторный и проектный метод, соединение обучения с производственным трудом и др.).

В отчете о проделанной работе за 1918-1920-е годы Московский подотдел профессионально-технического образования Московского отдела народного образования указывал на тяжелое положение в системе, в 
особенности осенью 1919 и на протяжении всего 1920 г.

Осенний призыв юношей на военную службу, ухудшающееся с каждым днем продовольственное положение, наступающие холода при полном отсутствии какого-либо топлива привели к тому, что зимой 1921 года почти вся учебная работа замерла. Но, несмотря на это, необходимо было подготовить высококвалифицированного рабочего, способного сразу включаться в рабочие процессы, нацеленного на результат. Это приводит к созданию школ фабрично-заводского ученичества, начавшемуся в 1920 году. Это была принципиально новая форма организации учебного процесса: подготовка молодого специалиста не в самом цеху, что требовало больших временных, людских (наставники) и финансовых затрат, а создание подобного мини-цеха (мастерской) при школе.

Наркомат просвещения СССР лишь спустя полтора года после ее возникновения, стал смотреть на ФЗУ не только как на очаг народного и всеобщего просвещения, но и как на самостоятельное перспективное профессионально-техническое учреждение. Наибольшее количество таких школ открылось в 1922-1923 годах, после выхода Закона о броне подростков в школах ФЗУ.

Уровень подготовки обучающихся в ФЗУ оставался различным. Исходя из этого, стало целесообразным определение нормативных сроков обучения по образовательным программам и приведение их к единому нормативу. Оптимальным для того периода был признан срок обучения 4 года в возрастной вилке подростка от 14 до 18 лет, те. до возраста взрослого рабочего. Так же был решен вопрос и о сокращении продолжительности рабочего дня и оплаты труда. В 1921 году средняя продолжительность рабочего дня для подростка составляла 6,4 часа, а ставка заработной платы равнялась $80 \%$ от ставки взрослого рабочего.

Отсюда вытекала необходимость рациональности при организации 
профессионального обучения и образования. Результатом этого явился проект единства общего, профессионального и политехнического образования в профессиональной школе, разработанный в 1920 году Н. К. Крупской и А. В. Луначарским.

На V съезде в прениях по докладу Луначарского оппонентами выступала группа деятелей Главпрофобра, Наркомпроса УССР и профсоюзов О. Ю. Шмидт, Б. Г. Козелев, Г. Ф. Гринько, выдвинувшие тезис о монотехническом образовании без четкого деления на общеобразовательные предметы и производственные практики: для рабочего были бы важны, прежде всего, профессиональные навыки, а общий уровень образованности оставался на втором месте.

Основной базой школ ФЗУ являлась семилетняя школа (или II ступень единой трудовой школы), но допускался и более низкий уровень в подготовке обучающихся.

1924 год поставил точку в этих спорах. 7 апреля 1925 года выходит положение о школах ФЗУ, четко определившее их как тип учебного заведения низшего профессионально-технического образования, дающий общеобразовательную подготовку в объеме школы-семилетки, а так же технические и специальные знания и обеспечивающий общественнополитическое воспитание передового советского рабочего.

Однако, в середине $1930-x$ гг. наступает перелом в развитии профессионального образования, связанный с общими тенденциями развития нашей страны.

Именно к этому времени Наркомпрос СССР окончательно поставил точку в спорах вокруг внедрения новых образовательных программ, практике их применения на местах. 25 июля 1930 года было опубликовано постановление ЦК ВКП (б) «О всеобщем обязательном начальном обучении», положившее 
конец педагогическим дискуссиям. В нем говорилось о необходимости решительной борьбы с «легкомысленным методическим прожектерством» в области образовательных программ: «всякая попытка оторвать перестройку образования от систематического и прочного освоения наук, в особенности естественно-технического и гуманитарного циклов, преподавание которых должно вестись на основе тщательно продуманных и взвешенных учебных планов, в соответствии с установленным расписанием, является грубейшим извращением идей перестройки и построения социалистической системы образования.» Обучающее начало вновь стало главенствовать над воспитательными аспектами образовательного процесса.

Нельзя сказать, что оно было вытеснено окончательно, но, в то же время, уступило место непосредственно получению знаний. Этот период в своих воспоминаниях описывает и первый директор Московского строительного техникума № 1 (ныне Колледж архитектуры и менеджмента в строительстве № 17) П. Н. Орлов: появляются стабильные образовательные программы и базисные учебные планы, аналоги которых по системам подготовки среднего образования существуют до сих пор. Например, базисный учебный план для подготовки техника по специальности «Строительство и эксплуатация зданий и сооружений», действующий по сей день, основан на Едином учебном плане, разработанном в 1930 году при открытии названного техникума. Именно тогда учебный план становится документом государственного уровня, единым для всей страны и для образовательных учреждений всех типов. Появляется ведомственность учебных планов при подготовке специалистов одного направления для различных отраслей народного хозяйства.

Четвертый этап (1940-1957 гг.) охарактеризован созданием и функционированием системы государственных трудовых резервов как системы профессионального образования, отразившей все реформаторские идеи, возникавшие в системе управления образования в целом, активизация 
разработки методики производственного обучения и становления системы подготовки индустриально-педагогических кадров.

На смену плюрализму и свободе приходит единообразие и жесткая централизация. Закрываются научные центры (Центральный институт труда) и ряд научно-педагогических журналов. В частности, ряд научных областей (педология, психотехника, психология труда) прекращает свое существование, что негативно отражается на содержании и методике профессионального образования. Это время характеризуется существенным обеднением методик образования, почти полным отсутствием образовательных практик, слабым развитием методической службы учреждений начального профессионального образования, нарушением их взаимосвязи с производственными и сельскохозяйственными предприятиями, являвшимися основными заказчиками квалифицированных кадров. Наряду с этим, усиливается значение теоретической подготовки, повышение качества уроков как основной формы получения профессионального образования.

Исследователи, занимавшиеся данной проблематикой, отмечают начало централизации и функционирования начального профессионального образования в условиях системы Государственных трудовых резервов, что обеспечивает стабильность, преемственность, плановость подготовки кадров. Однако, директивный характер теоретико-методического и организационного сопровождения профессионального образования, отказ от прогрессивного наследия прошлого, привели к негативным последствиям. Возможность оценить и преодолеть недостатки появляется лишь в конце 1950-х гг., когда отставание профессиональной подготовки от потребностей развития промышленности становится все более очевидным. Для анализа профессионального образования этого времени создаются специальные правительственные и ведомственные комиссии. 
Среди главных недостатков ими были названы: отставание педагогической теории от нужд подготовки кадров, низкий уровень методического обеспечения учебного процесса в образовательных учреждениях, в том числе начального профессионального образования.

\section{Литература:}

1. Малов С. Л. История профессионального образования в России /С. Л. Малов.-М. : ГБОУ ДПО Учебно-методический центр Департамента образования города Москвы, 2003. С. 11-18

2. Этапы большого пути: 70-летию трудовых резервов посвящается.-М. : ГБОУ ДПО Учебно-методический центр Департамента образования города Москвы, 2010. С.58-166

3. Декрет Совета Народных Комиссаров 3 декабря (20 ноября) 1917 года «О роспуске Государственного Комитета по народному образованию» // В. И. Ленин. О молодежи, Приложение 2-е, М.: Молодая гвардия, 1974. С. $465-$ 467.

4. ГАРФ. Ф. 1565 , Оп. 17, Д. 8060

5. Вендровская Р. Б. Отечественная школа 20-х годов: в поисках идеала / Р. Б. Вендровская.-М. : Новая книга, 1996. С. 18-21

6. Райков Б. Е. На жизненном пути Автобиографические очерки //СПФ АРАН. Ф. 893. Оп. 1. Справка о фонде

7. Райков Б. Е. На жизненном пути. Т. 5. С. 223 // СПФ АРАН. Ф. 893 Оп. 2 Д. 5

8. Естественно-историческое образование в СССР. Материалы I Всероссийского съезда педагогов-естественников 10-15 мая 1923 года. Стенографический отчет.-Л. : 1924.

9. Богуславский И. В. История Российской педагогики / И. В. Богуславский.Томск, Томь, 2005. С.215-225

10. Декрет ВЦИК 2 мая 1922 года «Об установлении предельного минимума 
количества подростков на предприятиях». // В. И. Ленин. О молодежи. Приложение 2-е, М.: Молодая гвардия, 1974. С. 511-513.

11. Декрет Совета Народных Комиссаров 29 июля 1920 года «Об учебной профессионально-технической повинности»// В. И. Ленин. О молодежи. Приложение 2-е, М.: Молодая гвардия, 1974. С. 497-498.

12. Луначарский А.В. Речь на $\mathrm{V}$ съезде РКСМ в прениях по докладу "Образование рабочей молодежи"// Пятый Всероссийский съезд РКСМ. май-июнь 1920. Стенографический отчет С.219-226.

13. Декрет СНК РСФСР то 31 июля 1925 года «об образовании школ фабрично-заводского ученичества //Государственный архив Кировской области. Ф. Р-1166 Оп. 170 ед. хр.

14. Богуславский И. В. История Российской педагогики / И. В. Богуславский.Томск, Томь, 2005. С. 125

15. Наследникам революции. Документы партии о комсомоле и молодежи. /Сост. Н. В. Трущенко и Б. И. Мышенков. - М. : Молодая гвардия, 1969. $592 \mathrm{c}$.

16. Этапы большого пути: 70-летию трудовых резервов посвящается.-М. : ГБОУ ДПО Учебно-методический центр Департамента образования города Москвы, 2010. С. 58-59

17. Указ. соч. С. 59-60

18. ГАРФ. Ф. Р-9661 Оп. 611 Д. 56 